\title{
Funeralne (nie)oczywistości i olśnienia
}

\section{Bogdan Mazan}

ORCID: $0000-0002-1085-5200$

(Uniwersytet Łódzki)

ReCENZJA KSiĄżKi: TAdeusz Budrewicz, PogrzebY PISARzy POLSKICH XIX hieku, Wydawnictwo Naukowe Uniwersytetu Pedagogicznego, KRAKów 2019, sS. $300+2$ NLB. ${ }^{I}$

Scjencja pracująca na rzecz funeralnego motywu omija czasem, krokiem do przodu, zwyczajowe tabu śmierci. Już bowiem „dokonało się”, po prostu „nie ma”, jak w tytule i treści niedawnej niedawno wydanej książki Mariusza Szczygła (Nie ma, Warszawa 20I8) i kilku innych, które poszły śladem Marcina Wichy, autora Rzeczy, których nie wyrzucitem (Kraków 20I7) lub samoistnie zmierzały do spraw zdeterminowanych wydarzeniem śmierci². Szczególne to zjawisko we współczesnej kulturze, honorującej wymienione dzieła prestiżowymi nagrodami i dobrymi recenzjami. Wzbudza przeto głos również literaturoznawców. Tadeusz Budrewicz zaczął pracę nad tematem wcześniej od wymienionych autorów, o czym świadczą opublikowane fragmenty jego nowej książki naukowej, ale byli też inni literaturoznawcy zainteresowani motywami funeralnymi w piśmiennictwie polskim XIX wieku ${ }^{3}$. Zbiór studiów Pogrzeby pisarzy polskich XIX wieku wchodzi w taki krąg kulturowy. A że go dopełnia i przekracza, to już kolejna sprawa.

Wobec wybitnie zasłużonych dla piśmiennictwa „pięknego wieku XIX”, wobec etykietalnych „odeszli”, zostali wtedy lub nadal są bliscy i dalsi potomni: czytelnicy

1 Odesłania do recenzowanej książki będą dalej sygnowane podaniem numeru stronicy w nawiasie.

2 Zob. z nowszej beletrystyki najbardziej udanej: W. Gogola, Po trochu, Wrocław 2017; M. Bieńczyk, Kontener, Warszawa 2018.

3 Zob. A. Pochłódka, Po śladach konduktu. O Mtodej Polsce za pośrednictwem motywów funeralnych, „Pamiętnik Literacki” 2007, z. 1, s. 93-123; zwłaszcza rozdz. I: Pogrzeb jako powszechnik kulturowy, s. 93-95. Podaję ten przykład, bo nie ma go w książce, która nie tylko poprzez bibliografię szeroko odnotowuje rozmaite uwikłania rozpatrywanej problematyki. Wiele użytecznej treści przedmiotowej sukcesywnie się w niej rozsiewa. Nieocenione w tym zakresie są uwagi, aby bibliograficznym adresem nie „robić reklamy nierzetelności badawczej” (s. 44, przyp. 54) oraz wskazania przy nazwisku i adresie bibliograficznym na stronniczość i niewiarygodność świadka zdarzeń (s. 63, przyp. 2). 
i wydawcy różnych pokoleń, a najpierw (współ)obecni i rówieśni - rodzina, żałobnicy, świadkowie, gorliwi admiratorzy i życzliwi inaczej, zaś na okoliczność samego aktu pożegnalnego, rozpisanego na pompa funebris bądź na skromny pochówek, ludzie $z$ wymienionych kategorii reagujący punktowo, na gorąco, domniemanie najbardziej szczerze; rzecz warta jest jednak falsyfikacji, którą Budrewicz skrupulatnie przeprowadził. Od tego wypadło zacząć obserwację jego książki, nietuzinkowej przy wszystkich możliwych a niewymienionych tu antecedencjach i przyległościach, więc dobrze zabezpieczonej przed szybkim śmiercionośnym starzeniem się, dotykającym już w chwili poczęcia wiele prac literaturoznawczych; notabene, ich pogrzeby też byłyby warte osobnego zainteresowania.

W zbiorze Budrewicza analizą zostały objęte kolejno pogrzeby następujących osób (tytuł określonego studium opuszczam, skracam lub streszczam): Maria Bartusówna, Jan Lam, Józef Ignacy Kraszewski, Bolesław Prus, Maria Konopnicka; jako „uwięzione w płci [...] kobiety-pisarki”, które pierwsze upomniały się o prawa kobiet - Eleonora Ziemięcka, Narcyza Żmichowska, Paulina Krakowowa, Anna Libera, Maria Ilnicka; jako samobójcy - Włodzimierz Stebelski, Rodoć (Mikołaj Biernacki), Michał Bałucki; w ramach „pożegnań [...] przed trasą”, związanych z transportem trumien - Aleksander Fredro, ksiądz Jan Koźmian, Stanisław Egbert Koźmian, Paweł Popiel, Włodzimierz Spasowicz. Ich ostatnie pożegnania zostały pedantycznie objaśnione i przeanalizowane, w rezultacie odczytane. W tle porównawczym znalazły się inne pogrzeby oraz niektóre głośne wydarzenia współczesne, na przykład przestępstwa.

Słowo / pojęcie „pogrzeb” ma w książce wiele zastosowań do bliskiej przeszłości, zatem nie omija „krokiem do przodu” tabu śmierci z jej uwarunkowaniami, czasem tak prozaicznymi jak ubóstwo ${ }^{4} \mathrm{i}$ tak w zawodzie pisarskim naturalnymi, jak: brak popularności, nieprzystawanie do zmienionych gustów, osłabienie weny pisarskiej. A dalej zwraca się do wielu aspektów i szczegółów z rutynowymi i osobliwymi komponentami, do bogatej otoczki i samej ceremonii pożegnalnej. Uwzględnia również, niebezkrytycznie, na przykład łącznie z elementami edytorskiej krytyki tekstu, odpowiednie piśmiennicze pokłosie w obrębie literacko-kulturowego kontekstu macierzystego. Wyświetla rozmaite, nie wszystkim przypadające wówczas do gustu, niekiedy domyślne lub życzeniowe $-\mathrm{z}$ racji zewnętrznych ograniczeń albo ideowo-środowiskowych barier - intencje i funkcje / akcenty pogrzebów: patriotyczne, narodowe, polityczne, integracyjne, tożsamościowe, uznaniowe, religijne, duchowe, wyznawcze, kulturowe. Nieczęsto mogły się one scalić lub w pełni

4 Autor wielokrotnie porusza kwestię trudnej materialnej pozycji literatów. Dopowiedzmy, że mogli być wtedy postrzegani jako zarazem "proletariat inteligencji” $i$,arystokracja ducha”. 
ujawnić. Działały wybiórczo, co zaś do jednej relacji budzą refleksję: jak trudno być nie tylko prorokiem, lecz także wybitnym pisarzem we własnym kraju.

Książka obejmuje dużo zasadniczych tematów, zjawisk i znaczących detali, organizacyjnych i logistycznych, ze sfery sacrum i profanum. Są to przykładowo (uporządkowanie pochodzi od recenzenta): okoliczności śmierci, wygląd zwłok, postawy wobec śmierci (widać czasem, że bardziej niż śmierci bano się umierania - to ludzki odruch), wystrój krypty, typowe i szczególne określenia charakteryzujące zmarłego, kierunki interpretacji jego ostatnich słów; rozpatrywane miejsca pochówku (Wawel, Skałka, Powązki...); nacechowanie przestrzeni ceremonialnej, „kontekst topografii pogrzebowej” (s. 24I), odtwórczy obraz i charakter pogrzebu (na przykład „pole bitwy", s. I03), wraz z przygotowanymi scenariuszem i scenografią przestrzenną (nierzadki dostrzeżony efekt - teatralizacja); dokumentacja ikonograficzna, oświetlenie (zapalone latarnie), wrażenia pod wpływem określonych efektów (na przykład jarzących się świec); skład społeczno-środowiskowy, personalny i liczebność żegnających zmarłego (są nazwiska i tytuły członków komitetów), pozornie bezimienny, a przecież nacechowany tłum (zliczony na miarę przybliżeń, po prostu „wszyscy” na pogrzebie Orzeszkowej, s. II4) oraz kogo i jakich grup albo czego należało się spodziewać, ale zabrakło (na przykład policji ${ }^{5}$, arystokracji, księży, uczniów, wieńców - jeśli taka była wola zmarłego), z zaznaczeniem, że było to bacznie obserwowane; porządek orszaku pogrzebowego, trasa konduktu, rodzaje i transport / przenoszenie trumien - często na barkach; stroje (narodowe, szlacheckie i na przykład „uroczysta kostiumologia”, s. 55); napisy na szarfach i wieńcach, rodzaj pieśni, flagi, chorągwie, plakaty; wymowna aura nagłośnień, ale i bezdźwięczność, na przykład sklepy zamknięte, „cisza żałobna” (s. 137) na pogrzebie Konopnickiej i wycieniowana „cisza ponura” (s. 197) na pogrzebie Anny Libery; zakazy władzy świeckiej i duchownej, w tym cenzorskie i policyjne; emanacja różnych kwestii społecznych i narodowych, uaktywniające się obozy ideowe, uwikłania prawno-administracyjne, polityczne i światopoglądowe; przepisy kościelne, racje teologiczne, implikacje i uwarunkowania międzynarodowe; próba "ujęcia geografii społecznej reakcji” (s. Io4), różne formy czci pośmiertnej, na przykład pomniki (projekty, realizacje, rekwizytornia, wyobrażenia), tablice pamiątkowe, składki, konkursy, zapisy, ofiarność na cele społeczne zamiast wieńców, gospodarowanie tekstami zmarłego, inne stosowne inicjatywy oraz przejawy kultu i recepcji; funeralne wynalazki, utrwalanie się i przemiany zwyczaju pogrzebowego; ocena moralności społeczeństwa oraz pozycji liderów życia zbiorowego (Kościoła, inteligencji, innych), konfrontacja etyki chrześcijańskiej z uniwersalnym kategoriami humanitarnymi, sensy wspólne i wspólnotowe, ale i zdeterminowanie kategorią płci; treści (nieraz w różnych 
wersjach i z uwzględnieniem rezonansu) przemówień, kazań, nekrologów, klepsydr, kondolencji, słowem, różne wypowiedzi okolicznościowe, także wierszowane (stosunkowo mało wierszy było po śmierci Prusa), czasem satyryczne; styl wypowiedzi, składających nie tylko oficjalny „dyskurs żałobny”, a więc słowa piękne, acz niekoniecznie prawdziwe, deklamatorstwo, grandilokwencja, retoryczność, wybujała uczuciowość, nastrojowość, kompilacja, plotkarstwo, rzeczowość, przenikanie się dyskursu sprawozdawczo-publicystycznego i religijnego, biegunowość - peryfrastyka i dosłowność - języka o samobójcach, nowoczesność, słowem, konwencje i zjawiska osobne. Wykreśla się nieogarnięta lista perpetua odniesień, którą trzeba tu przerwać. Można było ją inaczej podzielić na segmenty, skonfigurować lub bardziej skrócić, ale wtedy umknąłby funeralny potencjał. Jeśli jakiegoś z wymienionych elementów Budrewicz w jednostkowym przypadku nie podjąl, odbiorca dostrzeże „imponujące widowisko", na przykład na pogrzebie Popiela (s. 262).

Książka skłania do wytężonej uwagi, zasłuchań i zamyśleń zarówno nad objawami smutku i hołdu, wystawnej pompy i wyciszonego pożegnania, jak też nad okolicznościowym ostracyzmem, rozdźwiękiem, skandalem, głosem żarliwym i kaleczącym, bezwiednie lub mniej opatrznym oraz przekonaniowo odrębnym czy polemicznym. Ilustruje ostre starcia i spokojniejsze przebiegi dysput umownie nad grobem. Racje religii, Kościoła, nawet poszczególnych duchownych, wreszcie rozmaite ludzkie - nieczęsto bywały w zgodzie. Zwykle czas je tonizował. Niektóre, gdy czytelnik pójdzie śladem książkowych penetracji, mogą się wydać dziwnie aktualne, choć pieczołowicie zostały rozpatrzone jako historyczne symptomy wieku i cechy ważnych miejsc (Warszawa, Kraków, Lwów) na mapie podzielonego kraju. Czasem do takiej refleksji skłania urywkowe - stonowane, ale i wyrywające się - przydane słowo autorskie, dojrzałe, mądre, składające requiem dla wieku XIX, niekiedy ze wskazaniem, na przykład na liberalizm (s. 28I) czy awers i rewers losu pisarza (s. 198). Pointuje też ono zamknięcia epoki postyczniowej i rekonstrukcje „duchowego portretu zbiorowego generacji” (s. 99). Tak nie pisano dotąd o funeraliach ani o schyłku XIX stulecia.

Tyle jest w książce interesującego i dobrego co do podstaw, a nadto anioł tkwi w jej szczegółach. Wielce wymowna wydaje się bowiem nad podziw skrupulatna faktografia okolicznościowa, rejestrująca zjawiska wyjątkowe na tle szablonu. Kilka rudymentów i przejawów niekonwencjonalnych warto przybliżyć. Bo przecież rodza się przykładowe pytania. Czy w czymś się powtarzano? Czy silono się na oryginalność, jeśli to słowo jest w ogóle na miejscu? Czy był w przygotowaniach pogrzebu naglący, ale przemyślany zamysł, czy dominowało natchnione improwizowanie? Zwykle przeważała staranna i dopracowana w szczegółach organizacja według tradycyjnego schematu, co nie wykluczało nieprzewidzianych zakłóceń. Wyjątki 
dotyczyły niektórych samobójców, z oświetlonych w książce przyczyn, które - jak się okazuje - można było przezwyciężyć, na przykład w przypadku Bałuckiego.

Kto zechce, zauważy nurt podziemny książki, traktującej o ludziach wysokich, ale nierównych, niewymiernych czy nieporównywalnych zasług; wykaz sylwetek daje o tym pewne pojęcie. Czyni to zaś przez pryzmat osób żyjących. Wielcy, pomniejsi i mali kiedyś umrą, zostaną pogrzebani. Tak samo koryfeusze, jak pismacy i grafomani, rewindykatorzy i prześmiewcy znamienitych. W studyjnym zrównoważonym i zneutralizowanym dyskursie, co jest studiów wielką zaletą, tworzą oni jeden krąg wspomnieniowy, żałobny, milknący, choć widoczne są pobudzenia formą obrządku kościelnego, religijnego, świeckiego czy zgoła żadnego.

W związku z wieloaspektowo potraktowanym tematem książka, chcąc nie chcąc, dotyka rozmaitych strun $-z$ gruntu i podziemia zjawisk. Niektóre struny mogą się poruszyć jedynie u odbiorców mających przeżycia i doświadczenia graniczne. Cenne jest przeto dostrzeżenie, że „odeszli” pisali czasem prefiguracyjnie o sytuacjach granicznych, na przykład Bartusówna w wierszu Do śmierci (s. 44). Wskazane w tak rozległym rozpatrywaniu wrażliwych zjawisk neutralizacje oraz dystans (epicki i scjentystyczny) są przy tym optymalne. Oczywiście, o ile optimum jest możliwe, gdy piszący o funeraliach różnią się poglądami, upodobaniami, preferencjami. Nie jest więc tak, że nie widać podskórnych inklinacji Autora, gdy skrzętnie odnotowuje na przykład akcenty pozytywistyczne ${ }^{6}$. (A jakie treści miał odpoznawać, gdy niektórzy romantycy byli prepozytywistami, a w dobie Młodej Polski wystąpiła powracająca fala pozytywistyczna). Nigdy nie zaciemniają one poruszanych spraw. Myślę, że oddają sprawiedliwość twórcom i dociekliwości Autora, który może szuka jakiegoś aliażu w formie uromantycznionego pozytywisty czy wypatruje szlachetnej odwagi niezależnej od przekonań albo odwagi, by po prostu nie kłamać. Smętna przychodzi po lekturze myśl, że tej ostatniej na rozmaite sytuacje pogrzebu zbywało.

Nietrudno tu było o detaliczne potknięcia, rzeczowe lub ilustracyjne, tak samo jak niełatwo je wskazać i nie warto ich przesadnie szukać, gdy dokumentacyjno-faktograficzna zawartość książki jest wprost zaborcza. (Co nie znaczy, iż nie wolno się o nic spierać). Znalazłem raptem jedno dalszorzędne w związku ze słowami: „Kiedy łamy pozytywistycznej «Niwy» zdobiła winieta $z$ «lokomotywą postępu» wyjeżdżająca z tunelu niewiedzy” (s. IIo). Otóż nie była to winieta „Niwy”, lecz zreformowanego w I872 roku „Przeglądu Tygodniowego”, przedstawiająca lokomotywę z napisem „postęp”, funkcjonującym jako imię nadawane tego rodzaju pojazdom7 ${ }^{7}$ Wyjeżdżała ona pod parą z ciemnego tunelu. Prawie na jedno wyszło

6 Są też niezwykłe odczytania, np. sygnalizujące na pogrzebie Kraszewskiego „jakby symboliczne znaki od Boga" (s. 63).

7 Zob. W.Tomasik, Ikona nowoczesności. Kolej w literaturze polskiej, Wrocław 2007, s. 23. 
co do intencji Autora - podkreślenia trendu cywilizacyjnego - bo ówczesna „Niwa” miała na stronie tytułowej motto: „Wiedza to potęga”.

Nawet bez powoływania się na pragmatystów w rodzaju Richarda Rorty'ego czy inną pomocną w sprawie opinię $e^{8}$, należało tu wytworzyć lub, szukając, znaleźć odpowiedni język do analizowania tematu. Książka przynosi więcej, bo wskazuje również kulturowo-cywilizacyjne zmiany funeralnego języka epoki, tchnące polotem ku nowoczesności i spragmatyzowaną sensorycznością. Nie tylko zatem wypadło własny idiolekt powołać, lecz także ówczesny wychwycić - w ewolucji. Dlatego jeszcze należało przystanąć nad kwestią języka, że niemały szlak wytyczają w zbiorze piśmiennicze reakcje epoki. Takie mowy pogrzebowe, w ogóle wypowiedzi pośmiertne uwidocznione w druku, bywają kłopotliwe szczególnie dla weredyków i ludzi o zróżnicowanych poglądach, co może spotkać się harmonijnie w jednym. Śledząc książkę od początku pod tym kątem, trzeba rzec, że w dobitności sformułowań zwykle nie certowano się, poczynając od pogrzebu Goszczyńskiego.

Bardzo interesujące i przydatne do różnych celów stało się umieszczenie przy Konopnickiej osobnego działu Wiersze poetki, a w nim utworów pod tytułami: Zamiast wieńca na trumne (stąd można zaczerpnąć wiele emblematycznych ujęć dla pisania o Konopnickiej); Interteksty (stylizacje, cytaty, aluzje). W ostatnim z wymienionych członów wydobycie i przypisowe poświadczenie oddźwięku mogło być niełatwe, bo widać, że niektórzy twórcy czytali i zapamiętali Konopnicką niepowierzchniowo, tak samo jak ich zamysły musiał odczytywać Budrewicz. Są to zarazem utwory zapraszające do sensotwórczych odkryć. Dlatego zdaje mi się, że zawarty w następującym fragmencie wiersza Marii C. Przewóskiej-Heli Dusza Twoja „w grwiazdach czyta”: „Stąd dojrzałaś ten szlak bytu wysoki,/ Którym wiedzie w rozświt ducha - chrzest Boży” (s. I65) dość rzadki leksem „rozświt”, inicjujący przesłanie, może odsyłać do programowego kryptopatriotycznego wiersza Konopnickiej Na rozświcie (znanego z incipitu: „Nie mogę mówić...”), umieszczonego w pierwszym numerze redagowanego przez nią „Świtu” I884-18879. Dodatkowych odniesień, aluzji i tym podobnych, poza wskazanymi w książce, wolno dopatrywać się także $\mathrm{w}$ wierszach $\mathrm{z}$ działu Zamiast wieńca na trumnę. Skorzystam z tego na chwilę. Na przykład słowa z utworu Tadeusza Kończyca Pamięci Marii Konopnickiej:

8 Na okoliczność pisania o funeraliach Anna Pochłódka przywołuje opinię o młodopolskim „bogatym mówieniu” o śmierci jako „w gruncie rzeczy dość schematycznej retoryce, jako próbie stworzenia języka dla zjawiska, które się językowi wymyka” (Po śladach konduktu..., s. 122-123). Stąd płyną określone wnioski.

9 Zob. M. Konopnicka, Poezje, wyd. zupełne kryt., t. 2, oprac. J. Czubek, wstęp H. Sienkiewicz, Warszawa [1915-1916], s. 185-186 [tutaj pod tytułem Fragmenty]. 


\section{\Do pracy trzeba stawać znów \\ I wiązać się w łańcuchy, \\ Brak nam jednakże Twoich słów - \\ Nadziei i otuchy... (s. 157),}

jeśli stanowią, jak opowiada się Budrewicz w przypisie do drugiego przytoczonego wyżej wersu, „możliwą aluzję do Ody do mtodości A. Mickiewicza” (s. 157, przyp. 44), to prawdopodobnie mogą być również bliższą chronologicznie aluzją do strofy z wiersza Konopnickiej Bądź silnym!:

\section{\Garstka szlachetnych, co przyszłość zdobywa, Jest jako luźne słoneczne ogniwa, Które się w całość połączyć nie mogą... I brak im może właśnie twego ducha, By zamknąć kręgi wielkiego łańcucha, Co glob opaszą i nową pchną drogą ${ }^{\mathrm{IO}}$.}

W niej Konopnicka nawiązuje do wymienionego wiersza Mickiewicza, dając „słowa nadziei i otuchy”, których brak odczuwał Kończyc, uruchamiający (hipotetycznie) dwuetapowy ciąg aluzji.

W namysł mogą też wprawić słowa z wiersza Domosławy Do wieszczki: „Skąd wiesz, że cierpi dziewczyna/ hańbą okryta" (s. r6I), odniesione w książce Budrewicza do rozpatrywanego przez Konopnicką „problemu dzieci pozamałżeńskich” (s. I6I, przyp. 50). Jeśli jednak uzna się, że przyczyną cierpienia może być dla kobiety hańbiąca praca, to przypomni się zapomniany wiersz Konopnickiej Na dnie przepaści, opisujący domniemanie, ale wystarczająco czytelnie, dom rozpusty, „miejsce bezcześci”, w którym „hańba ściera na upadku progu/ Z czół młodocianych [kobiet] jasne ducha piętna”, a cierpienie wybrzmiewa „jakoby skarga nad świeżą mogiłą, „boleści językiem”, „łzami [...] gorącymi” ${ }^{\text {II }}$. Tyle gwoli zaznaczenia otwartości książki i wszelakich taktownych zaproszeń z jej strony.

Dowodnie - faktograficznie, dokumentacyjnie i dyskursywnie - okazuje się dzięki studiom Budrewicza, że pogrzeb osób znanych w epoce i poza nią, wybitnych w piśmiennictwie, stanowiących w okresie zaborów „zastępczą elitę przywódczą” (s. 5), zostawia widoczny dosiężny ślad; że staje się nie tylko żałobną ceremonią. Widać bowiem, jak tematycznie się otwiera wielowymiarowo, o ile zostaną użyte odpowiednie kody dostępu do źródeł. Widać, ile ma treści wiadomych i oczeki- 
wanych, uświęconych tradycją, jak też niespodzianych i przygodnych. Są to więc $\mathrm{w}$ rezultacie rozmaite interludia i oprawy, wielokształtne aplikacje do różnych form czasu, obyczaju, życia społeczno-politycznego i niezbywalnych uwarunkowań. Są to umowne lub okazją żywiej poruszone akty mniej lub bardziej uroczyste, zdobnicze, siewne, ale i wymowne przerywniki, przemilczenia, docinki i jątrzące polemiki. Krótko mówiąc, tak ilustrowany pogrzeb niesie przedsłowie, ornamentacyjny fundament, konstrukt sięgający w nieboskłony, ale i trawiącą całość rdzę ludzką. A studia Budrewicza wypełniają taki obszar. Wymienione na początku tej recenzji beletryzacje wydają się w ich świetle wyjątkowo niepełne wobec zakresu możliwości i kompetencji w temacie. Zrozumiałe, bo są to regiony refleksji niewspółmierne. Jednak - czy rzeczywiście?

Sygnaturą i treścią firmową książki są ogarnięte złożonym warsztatem polihistora literatury złoża poznawczo nieprzecenione i wieloaspektowo inspirujące, wykonane jakby na dopełnione ikoniczne zamówienie wszystkich składowych tytułu „Napisu”: Hołd [wiekopomny], laudacja [tuż po życiu, jednak zakłócana], pamiq̨tka w literaturze i kulturze [funeralna, wyjątkowa]. Owszem, wystukuje się memento mori, ale po to, ażeby przytomnie wyjść z żałobnego cienia ku chcącym pamiętać. Istotnie rzecz jest warta pamięciowego zaczytania się - z przystankami - i niejednej recenzji. 